\title{
Painting by night
}

\begin{abstract}
Van Gogh and the Colors of the Night The Museum of Modern Art, New York Until 5 January 2009 and then at the Van Gogh Museum, Amsterdam, from 13 February to 7 June 2009.
\end{abstract}

Van Gogh and the Colors of the Night, an exquisite exhibition now on show at the Museum of Modern Art in New York, explores this artist's fascination with portraying the night. Unlike earlier artists who painted night scenes by day from memory, Vincent van Gogh painted his nocturnal scenes on the spot, using gaslight and colour in innovative ways to depict sunset and starlight in luminous yellow tones. As the exhibition's curator Joachim Pissarro explains, van Gogh was the first artist "to blend together gaslight - artificial, urban light - with starry light in a painting". Both lights blaze with "the same kind of buzzing, bursting of energy, a kind of weird kinship".

That "weird kinship" is captured perfectly in van Gogh's 1888 work The Starry Night Over the Rhône (pictured), his first attempt to paint the stars. The Great Bear constellation burns green in the sky, while across the river, the distant orange gas lamps of the French town of Arles are reflected in the water like the stars' earthly companions. Gas lamps gleam with the same fierce energy in The Night Café, a sparsely occupied saloon that van Gogh painted during three sleepless nights in 1888. The glare of the four gas lamps hanging from the ceiling combines

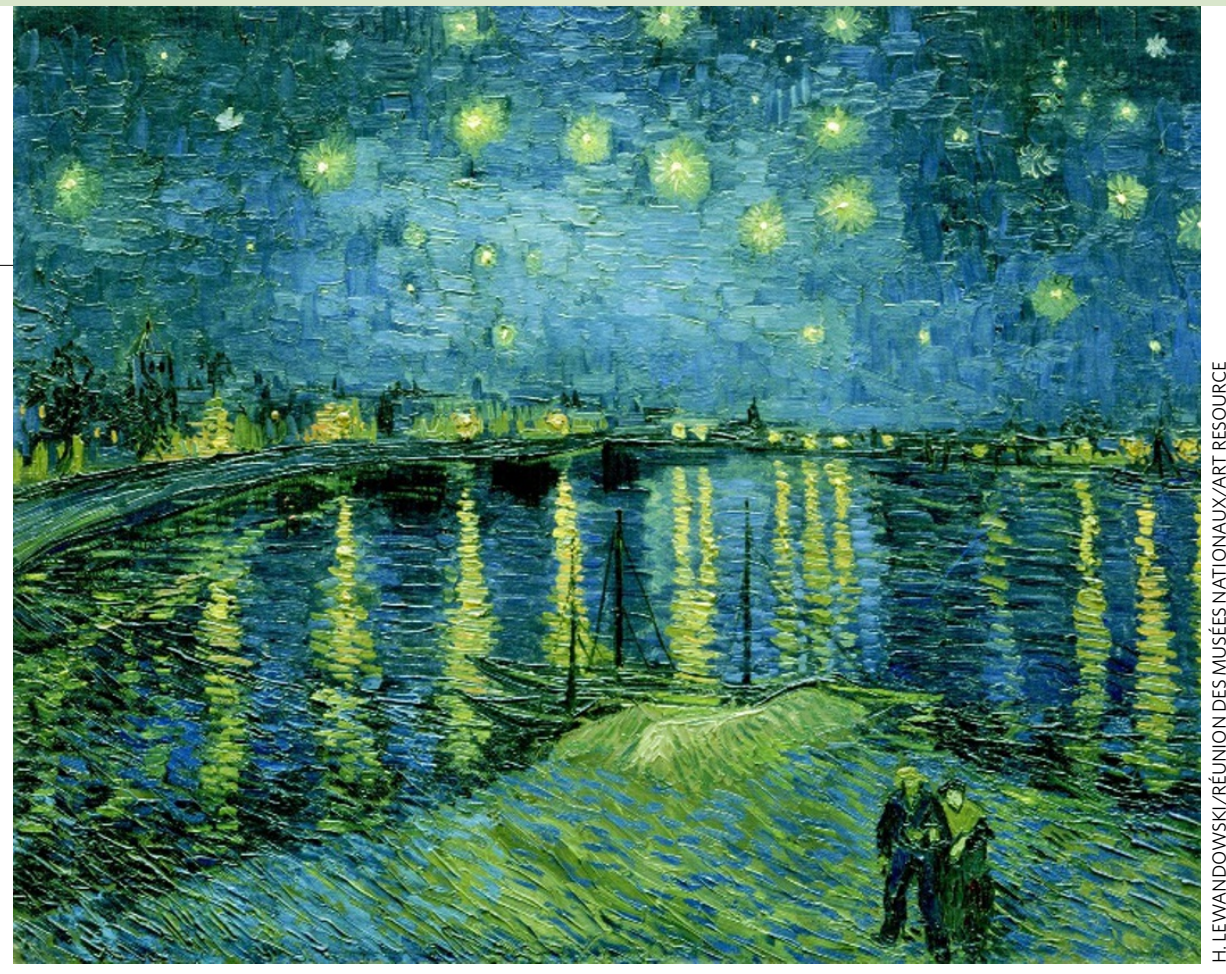

with the painting's high-pitched palette of greens and reds - six or seven shades from "blood-red to delicate pink" - to evoke, as the artist wrote, "the terrible human passions". The melancholy of this scene contrasts sharply with the joyful hubbub of The Dance Hall in Arles (1888), exhibited here beside The Night Café for the first time; the golden orbs of the gas lamps bathe the dancers in a warm and vibrant light.

These bright, spirited scenes seem eons away from van Gogh's earlier, muddy-dark depictions of country cottages and peasants. In his first significant interior night scene, The Potato Eaters, painted in 1885, a single oil lamp casts a pallid glow over the rough faces of the farmers as they share their meagre meal. In The Cottage, painted the same year, a narrow gash of sunset sky and the smudge of an oily flame in a window are all that animate the greenblack evening shadows. The light of oil lamps may also be glimpsed inside the houses of The Starry Night, the exhibition's most magnificent work. Van Gogh painted it in June 1889 - a year before his suicide - while confined in an asylum at Saint-Rémy in the south of France. In this delirious vista, clouds churn, the crescent Moon shines like a roiling Sun, and tall cypress trees tower in the foreground as symbols of death and the afterlife. Beneath them, the houses of the village stand serenely, their windows squares of comforting yellow light - beacons of the life inside.

Josie Glausiusz is a journalist based in New York. e-mail: josiegz@earthlink.net

\section{Science at the movies}

\author{
Imagine Science Film Festival \\ New York City, New York \\ 16-25 October 2008 \\ CinemaScience \\ Village CinemaScience, Bordeaux, France \\ 16-26 October 2008
}

When scientists appear on the big screen, if at all, they tend to be going mad or else paying for their hubris - think Dr. Strangelove, Jurassic Park and A Beautiful Mind. This month, two new film festivals - the Imagine Science Film Festival in New York (www.imaginesciencefilms.com) and CinemaScience in Bordeaux, France (www.cnrs.fr/cinemascience) - aim to correct this impression. Privileging fiction over documentary, they show how to tell stories grounded in real research.

The Imagine festival, sponsored by Nature, began as a series of screenings at New York's
Rockefeller University by biologist Alexis Gambis. Illness is the villain in many of the chosen short films, from Jen Peel's medical thriller Muerto Canyon, about a deadly virus in New Mexico, to Toddy Burton's The Aviatrix, about the superhero alter-ego of a woman struggling with cancer. Some of the best use humour. California King, directed by Eli Kaufman, is the tale of a mattress salesman who falls for an insomniac, and it is leavened with ironically placed lessons in Newtonian mechanics. Like the wordless opening of Disney-Pixar's $W A L L \cdot E$, the post-apocalyptic Pygmalion story Lone, from Andrew Nowrojee, has some of the pathetic charm of Buster Keaton.

A pair of pulse-quickening features in Spanish round out the programme: La Habitación de Fermat (Fermat's Room; 2007), a thriller about a group of mathematicians forced to solve word problems or die, and Alex Rivera's
Sleep Dealer (2008), in which virtual labour and water politics make for a Mexican Star Wars with a Marxist twist. The festival also screens Paul Devlin's stranger-than-fiction documentary BLAST! (2006), about astrophysicists travelling to Antarctica to launch a telescope on a high-altitude balloon.

The CinemaScience festival in Bordeaux is sponsored by the CNRS, France's basic-research agency. The festival examines Hollywood's reliance on scientific innovation as a source of disaster, with retrospectives of classics from Fritz Lang's Metropolis (1927) to James Cameron's Terminator II (1991). As a mild corrective, Exodus Film Group's new animated feature Igor, about a hunchbacked lab assistant who hopes to win the Evil Science Fair, promises to poke gentle fun at common misperceptions. Other films engage more seriously with the history of science. The biopic Korolev (2007), directed by Yuri Kara, follows the career of the Russian rocket scientist who survived Stalin's labour camps to launch Sputnik 